\title{
Making Peace
}

\author{
THE RECONSTRUCTION \\ OF GENDER IN \\ INTERWAR BRITAIN
}

Susan Kingsley Kent

PRINCETON UNIVERSITY PRESS

PRINCETON, NEW JERSEY 
Copyright $(1993$ by Princeton University Press Published by Princeton University Press, 41 William Street, Princeton, New Jersey 08540

In the United Kingdom: Princeton University Press, Chichester, West Sussex

All Rights Reserved

Library of Congress Cataloging-in-Publication Data

Kent, Susan Kingsley.

Making peace : the reconstruction of gender in interwar Britain / Susan Kingsley Kent.

p. $\mathrm{cm}$.

Includes bibliographical references and index.

ISBN 0-691-03140-1

1. Sex role-Great Britain-History-20th century.

2. Feminism-Great Britain-History-20th century. 3. War and society.

I. Title.

HQ1075.5.G7K46 1993

305.3'0941'0904--DC20 93-18776

This book has been composed in Adobe Caledonia

Princeton University Press books are printed on acid-free paper and meet the guidelines for permanence and durability of the Committee on

Production Guidelines for Book Longevity of the Council on Library Resources

Printed in the United States of America

$\begin{array}{llllllllll}1 & 3 & 5 & 7 & 9 & 10 & 8 & 6 & 4 & 2\end{array}$

Princeton Legacy Library edition 2019

Paperback ISBN: 978-0-691-65537-6

Hardcover ISBN: 978-0-691-65679-3 
For Anne 
